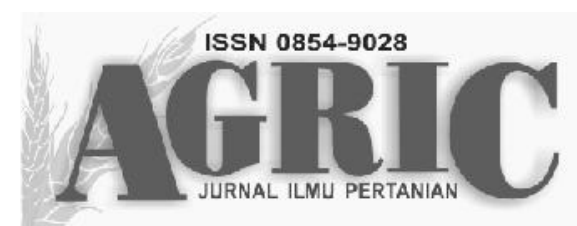

Fakultas Pertanian dan Bisnis Universitas Kristen Satya Wacana Jl. Diponegoro 52-60 SALATIGA 50711 - Telp. 0298-321212 ext 354 email: agric_fpb@yahoo.co.id, website: ejournal.uksw.edu/agric

\title{
PENENTUAN KONSENTRASI KEMATIAN KALUS TEBU (Saccharum officinarum) VARIETAS BL DAN PS-862 PADA SELEKSI In Vitro UNTUK KETAHANAN TERHADAP SALINITAS
}

\section{LETHAL CONCENTRATION DETERMINATION OF SUGARCANE (Saccharum officinarum) CALLUS, BL AND PS - 862 VARIETIES In Vitro SELECTION FOR RESISTANCE SALINITY}

\author{
Parnidi \\ Balai Penelitian Tanaman Pemanis dan Serat. J1. Raya Karangploso. P.O. Box 199. Malang \\ nikicro@yahoo.co.id \\ Nurlaila Shofianita \\ Jurusan Biologi. Fakultas Matematika dan Ilmu Pengetahuan Alam. \\ Institut Teknologi Sepuluh Nopember (ITS) \\ J1. Arief Rahman Hakim. Surabaya 60111 Indonesia \\ Tutik Nurhidayati \\ Jurusan Biologi. Fakultas Matematika dan Ilmu Pengetahuan Alam. \\ Institut Teknologi Sepuluh Nopember (ITS) \\ Jl. Arief Rahman Hakim. Surabaya 60111 Indonesia
}

Diterima 26 April 2016, disetujui 11 Juli 2016

\begin{abstract}
Salinity (salt stress) is one of the different causes of decline in crop yields and productivity of sugarcane. One strategy for optimizing the production of sugarcane on saline land required tolerant varieties of salinity. This research was conducted to determine NaCl concentration that caused more than $>90 \%$ callus death on sugarcane ( $S$ officinarum) tissue culture and to investigate the protein profile of sugarcane callus BL and PS-862 varieties on saline (NaCl) stress condition. Sugarcane BL and PS-862 varieties were obtained from tissue culture. and those callus were sub-cultured in salinity media with composition of MS (Murashige-Skoog) as base medium and $\mathrm{NaCl}$ in various concentration (0\%; $0.25 \% ; 0.5 \% ; 0.75 \%$; and 1\%). The results showed condition of $\mathrm{NaCl}$ addition on media by $1 \%$ concentration cause alteration on morphology of callus that $75 \%$ part of whole tissues become dark brown coloured that indicating the tissues death. At four weeks after sub-culture, the calli on both varieties obtain score 4. Lethal percentage of both varieties BL and PS-862 in 1\% NaCl was 91,67\%. This result were supported by protein profile analysis. that a thinner protein band in $1 \% \mathrm{NaCl}$ treatment compared with control. This is indicating that in salinity stress causing the decrement of protein expression.
\end{abstract}

Keywords : NaCl Concentration. Sugarcane ( $\underline{\text { Sofficinarum}})$. Salinity Stress. Protein Profile. 


\section{PENDAHULUAN}

Saat ini terjadi ketidak seimbangan antara produksi dan konsumsi gula. Peningkatan kebutuhan konsumsi gula dalam negeri yang lebih besar dibandingkan peningkatan produksi gula sehingga terjadi defisit gula. Defisit gula nasional sudah terjadi sejak tahun 1967 dan terus mengalami peningkatan sehingga kebutuhan gula nasional terpaksa harus dipenuhi melalui impor gula. Selama kurun waktu 2002-2010 produktivitas tebu berkisar antara 67,1 - 81,8 ton/ha dengan rendemen antara 6,47-8,20\% (Ditjenbun, 2011). Sementara itu kebutuhan gula pada tahun 2014 sekitar 5.7 juta ton. Guna memenuhi kebutuhan gula nasional dapat ditempuh dengan beberapa cara diataranya meningkatkan produktivitas tebu, rendemen gula dan dengan perluasan areal (ekstensifikasi) (Haryono, 2011).

Usaha perluasan lahan mengalami beberapa kendala di mana lahan produktif untuk pertanian semakin berkurang dan yang tersedia adalah lahan marjinal. Salah satu lahan marjinal yang belum termanfaatkan adalah lahan salin. Di Indonesia, total luas lahan salin 440.300 ha yang terbagi menjadi lahan agak salin (304.000 ha) dan lahan salin (140.300 ha) (Rachman et al. 2007). Pemanfaatan tanah salin menjadi areal pertanian banyak mengalami hambatan.

Salinitas menjadi faktor pembatas pertumbuhan tanaman, yang menghambat pertumbuhan melalui penurunan biomassa (Essa \& Al - Ani 2001), sehingga menurunkan hasil (Pathan et al. 2007). Salinitas adalah konsentrasi garam-garam terlarut dalam jumlah besar yang dapat mempengaruhi pertumbuhan kebanyakan tanaman. Pengaruh salinitas pada tanaman sangat kompleks. Salinitas akan menyebabkan stres ion, stres smotik dan stres oksidatif (Kusmiyati et al., 2009; Munns et al., 2006).

Secara agronomi, strategi untuk menanggulangi permasalahan lahan marjinal tersebut dengan memanfaatkan tanaman yang toleran terhadap cekaman salinitas (Utama et al. 2009). Tetapi upaya penggunaan varietas toleran salinitas hingga saat ini masih terkendala oleh terbatasnya ketersediaan varietas tebu unggul hasil tinggi dan toleran salinitas.

Perakitan varietas tebu yang toleran salinitas dapat diawali dengan seleksi keragaman atau variasi somaklonal secara in vitro terhadap kalus tebu. Seleksi ketahanan terhadap kadar salin tersebut dapat dilakukan jika diketahui konsentrasi ambang batas maksimal yang dapat diterima oleh pertumbuhan tanaman tebu (S officinarum). Untuk mengetahui ambang batas salinitas dilakukan penelitian seleksi dengan menggunakan $\mathrm{NaCl}$ yang dapat menyebabkan kematian kalus 90\%, dapat dilakukan seleksi kalus yang mampu hidup pada media yang mengandung $\mathrm{NaCl}$ dalam jumlah tertentu. Konsentrasi lethal yang dimaksud $\mathrm{NaCl}$ maksimal yang dimaksud adalah konsentrasi yang mampu menyebabkan kematian kalus $>90 \%$ dan sisanya merupakan kalus yang masih mampu bertahan hidup (Purwati, 2007). Berdasarkan penelitian Farid et al. (2006) konsentrasi 1,2\% merupakan batas ketahanan untuk seleksi tingkat ketahanan tebu terhadap salinitas. Berdasarkan permasalahan tersebut maka perlu dilakukan penelitian untuk mengetahui konsentrasi $\mathrm{NaCl}$ yang menyebabkan kematian kalus lebih dari $90 \%$.

\section{METODE PENELITIAN}

Penelitian dilaksanakan mulai bulan Januari sampai dengan April 2013, di Laboratorium Kultur Jaringan Balai Penelitian Tanaman Pemanis dan Serat, Malang. Bahan penelitian yang digunakan adalah dua varietas tebu yaitu $\mathrm{BL}$ dan PS 862. Konsentrasi $\mathrm{NaCl}$ yang digunakan $0 \% ; 0,25 \% ; 0,5 \% ; 0,75 \%$; dan $1 \%$. Masing-masing perlakuan terdiri atas 12 botol, diulang 3 kali. Tahapan dalam kegiatan ini adalah sebagai berikut: 


\section{Induksi kalus}

Eksplan tanaman tebu yang digunakan adalah daun tebu yang masih menggulung yang diinokulasikan pada media induksi kalus yaitu media MS (Murashige-Skoog) dengan tambahan ZPT 2.4-diklorofenoksiasetat (24-D) 3 ppm. Perlakuan ini dilakukan selama 8 minggu sehingga didapatkan kalus tebu dalam jumlah cukup untuk percobaan berikutnya.

\section{Seleksi kalus pada media salin}

Kalus tebu dengan berat $0.1 \mathrm{~g}$ disub-kulturkan pada media seleksi yaitu media dasar MS yang ditambah $\mathrm{NaCl}$ dengan konsentrasi $0 \% ; 0.25 \%$; $0.5 \% ; 0.75 \%$; dan $1 \%$ selama 4 minggu. Setelah diperoleh konsentrasi yang sesuai kalus disubkultur kembali pada media yang sama. Pada 1 minggu setelah sub-kultur, dilakukan uji profil protein dengan metode SDS-PAGE terhadap kalus yang memiliki tingkat kematian $>90 \%$. Data yang diperoleh dilakukan analisis deskriptif untuk mengetahui respon masingmasing varietas terhadap konsentrasi $\mathrm{NaCl}$.

\section{Skoring Kalus}

Kondisi morfologi kalus berbeda-beda setelah ke media salin ( $\mathrm{MS}+\mathrm{NaCl})$, untuk mengamati kerusakan kalus akibat $\mathrm{NaCl}$, dilakukan scoring dengan nilai 0-4, sebagai berikut:

Skor 0 : kalus sehat. berwarna putih

Skor 1 : kalus kurang dari $25 \%$ berwarna coklat Skor 2 : kalus antara $26-50 \%$ berwarna coklat Skor 3 : kalus antara $51-75 \%$ berwarna coklat Skor 4 : kalus lebih dari $75 \%$ berwarna coklat
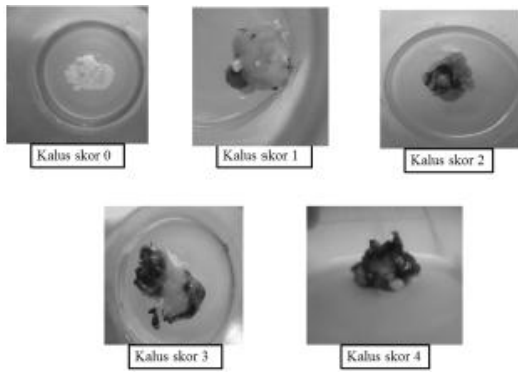

Gambar 1 Kondisi morfologi kalus tebu (Saccharum officinarum) varietas BL berdasarkan nilai skoring (Dokumentasi Pribadi. 2013).

\section{Uji Profil Protein}

Setelah melalui tahap seleksi awal berupa penentuan konsentrasi kematian pada kalus tebu, maka kalus yang masih mampu bertahan hidup dilakukan subkultur kembali ke dalam media dengan konsentrasi yang sama selama 1 minggu. Selanjutnya sampel kalus hasil kultur jaringan tersebut dilakukan uji elektroforesis SDS-PAGE dengan menggunakan Marker standard protein untuk mendapatkan profil protein berdasarkan pita berat molekulnya.

\section{HASIL DAN PEMBAHASAN}

\section{Morfologi Kalus}

Pengamatan morfologi kalus dilakukan dengan menghitung rata-rata nilai skor 12 botol kultur jaringan tebu ( $S$ officinarum) varietas BL dan PS-862 untuk masing-masing media yang mengandung $\mathrm{NaCl}$ dengan konsentrasi yang berbeda. Skor morfologi kalus mengalami kenaikan tiap minggu pada konsentrasi $\mathrm{NaCl}$ yang berbeda, pada kedua varietas. Gambar 1 menunjukkan nilai rata-rata skor morfologi kalus varietas BL dan PS 862 pada berbagai konsentrasi $\mathrm{NaCl}$.

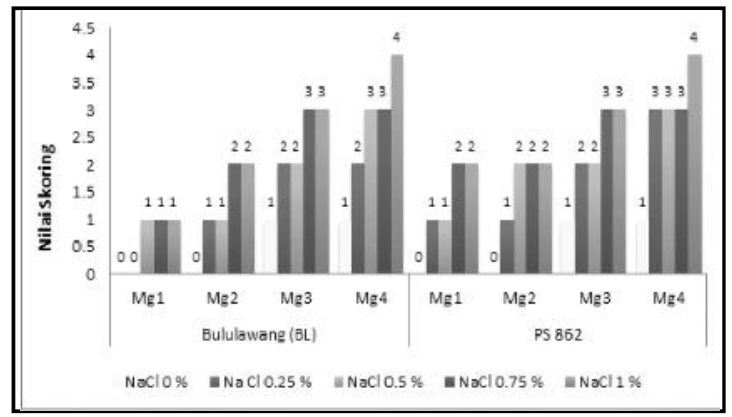

Grafik 1 Rata-rata nilai skoring morfologi kalus varietas BL dan PS 862 pada minggu ke 1 sampai dengan minggu ke 4 setelah dikultur pada media yang mengandung $\mathrm{NaCl}$.

Skor morfologi kalus mengalami kenaikan secara berkala pada setiap minggu dan setiap kenaikan konsentrasi $\mathrm{NaCl}$ dalam media. Pada varietas BL minggu pertama menunjukkan skor 0 untuk 
kontrol dan perlakuan $\mathrm{NaCl} 0,25 \%$, namun pada perlakuan $\mathrm{NaCl}$ 0,50\%; 0,75\% dan $1 \%$ masingmasing menunjukkan nilai skor 1 . Hal ini berarti bahwa konsentrasi $\mathrm{NaCl}$ pada media berpengaruh terhadap kalus tebu (S officinarum) varietas BL. Selanjutnya pada minggu kedua, perlakuan kontrol masih menunjukkan nilai skor 0 , yang berarti kalus masih sehat. Namun pada perlakuan $\mathrm{NaCl} 0,25 \%$ dan 0,50\% menunjukkan nilai skor 1 , yang berarti kurang dari $25 \%$ bagian dari kalus mulai berwarna coklat. Sedangkan perlakuan $\mathrm{NaCl} 0,75 \%$ dan $1 \%$ sudah menunjukkan skor 2, yaitu kurang dari 50\% bagian kalus berwarna coklat. Pada minggu ketiga dan keempat, perlakuan kontrol menunjukkan skor 1 .

Kalus pada perlakuan kontrol mengalami pencoklatan (browning). Browning dapat terjadi pada kalus tebu karena tebu memiliki kandungan senyawa fenolik yang apabila teroksidasi dengan $\mathrm{O}_{2}$ akan membentuk senyawa Quinon (Benyamin. 1993). Menurut Watson et al. (1988), apabila sel-sel kalus dilukai maka sel-sel baru akan cenderung tumbuh menutupi lukanya dan seiring berjalannya waktu senyawa-senyawa fenol akan tertimbun dalam sel-sel ini dan mengeraskan serta menutup jaringan lukanya secara efektif. Pelukaan kalus terjadi pada waktu dilakukan subkultur, sehingga senyawa-senyawa fenol yang tertimbun menyebabkan kalus tebu berwarna coklat. Pada penelitian ini, penambahan $\mathrm{NaCl}$ dalam media mengakibatkan kalus berwarna kecoklatan. Warna kalus semakin coklat hingga pekat kehitaman, yang akhirnya membusuk sejalan dengan kenaikan konsentrasi $\mathrm{NaCl}$. Bahkan pada minggu keempat, perlakuan $\mathrm{NaCl} 1 \%$ menyebabkan lebih dari $75 \%$ bagian kalus berwarna coklat/kehitaman (skor 4). Kalus dengan nilai skor 4 ini merupakan kalus-kalus tebu (Sofficinarum) yang lolos seleksi awal. sehingga dapat diaplikasikan pada tingkat seleksi yang lebih tinggi.

Pada varietas PS 862 untuk minggu pertama perlakuan kontrol masih menunjukkan skor 0 , namun pada media MS yang ditambah $\mathrm{NaCl}$ $0,25 \%$ sudah mampu menghasilkan kalus dengan nilai skor 1 demikian pula apabila konsentrasi ditingkatkan menjadi $0,50 \%$. Selanjutnya pada konsentrasi $0,75 \%$ dan $1 \%$ nilai skor menjadi 2 , dan tidak berubah dari minggu pertama sampai dengan minggu ke dua. Pada perlakuan konsentrasi $0.50 \%$ mulai menunjukkan skor 2 , yang pada minggu sebelumnya menunjukkan nilai skor 1 . Sama halnya untuk minggu ketiga dan keempat pada varietas BL kalus varietas PS-862 juga menunjukkan skor 1 untuk perlakuan kontrol dan pada konsentrasi $1 \%$ mingggu keempat kalus ini juga menunjukkan nilai skor 4. Sel-sel kalus pada kondisi $\mathrm{NaCl} 1 \%$ mengalami tanda-tanda penurunan fisiologis akibat akumulasi $\mathrm{NaCl}$ dalam konsentrasi tinggi. Dalam hal ini ditunjukkan dengan kondisi morfologi kalus yaitu lebih dari 75\% bagian sel-sel kalus berwarna kecoklatan bahkan sampai hitam.

Berdasarkan penelitian Ashraf (2007), cekaman $\mathrm{NaCl}$ menyebabkan berbagai efek fisiologis pada tanaman seperti laju respirasi meningkat, toksisitas ion, perubahan pertumbuhan tanaman, distribusi mineral dan ketidak-stabilan membran yang dihasilkan dari perpindahan kalsium oleh natrium, permeabilitas membran dan penurunan tingkat fotosintetik. Selain itu, Turkmen et al. (2002) menyatakan bahwa sebagian besar tanaman budidaya sensitif terhadap cekaman $\mathrm{NaCl}$, karena salinitas $(\mathrm{NaCl})$ dapat menyebabkan ketidak-tersediaan air dan ketidak-seimbangan serapan hara oleh tanaman, penghambatan metabolisme akibat gangguan ion beracun dan efek osmotik. Pada morfologi kalus yang teramati adalah berupa perubahan warna sel menjadi kecoklatan dan akhirnya membusuk. Hal tersebut terjadi sebagai akibat cekaman $\mathrm{NaCl}$ dalam jangka waktu lama, maka fungsi-fungsi fisiologis sel akan cenderung mengalami penurunan secara berkala dan selanjutnya selsel tersebut akan mengalami kematian jika tidak 
mampu beradaptasi terhadap kondisi cekaman garam $\mathrm{NaCl}$.

Daya adaptasi terhadap kondisi salin varietas BL cenderung lebih baik dibanding varietas PS862 terutama minggu-minggu awal. Namun pada minggu ke-4, morfologi kedua varietas ini terlihat sama, hal tersebut dibuktikan berdasar hasil skoring morfologi pada kedua varietas yang mendapat nilai skor sama yaitu 4 (Gambar 1).

Menurut Welsh (1991) jika terdapat perbedaan antara dua individu pada lingkungan yang sama dan dapat diukur, maka perbedaan ini berasal dari variasi genotipe kedua tanaman tersebut. Dengan demikian. kedua varietas tersebut mengalami perbedaan dalam hal proses adaptasi terhadap kondisi salin yang ditimbulkan oleh konsentrasi $\mathrm{NaCl}$ dalam media.

\section{Persentase Kematian Kalus}

Persentase kematian kalus dinyatakan dengan hasil skoring morfologi kalus, dimana kalus dengan skor 4 dianggap sebagai kalus mati. Pada skor 4 dengan kondisi kalus lebih dari $75 \%$ berwarna coklat atau mati, diasumsikan bahwa kalus tersebut akan sulit untuk mengalami regenerasi kembali. Data hasil perhitungan persentase kematian kalus tebu seperti yang tersaji pada Tabel 1 .

Tabel 1 Persentase kematian kalus tebu varietas BL dan PS-862

\begin{tabular}{lccccc}
\hline \multirow{2}{*}{ Varietas } & \multicolumn{5}{c}{ Konsentrasi NaCl dalam media } \\
\cline { 2 - 6 } & $\mathbf{0 \%}$ & $\mathbf{0 . 2 5 \%}$ & $\mathbf{0 . 5 0 \%}$ & $\mathbf{0 . 7 5 \%}$ & $\mathbf{1 \%}$ \\
\hline BL & $0 \%$ & $0 \%$ & $0 \%$ & $8.33 \%$ & $91.67 \%$ \\
PS-862 & $0 \%$ & $0 \%$ & $0 \%$ & $16.67 \%$ & $91.67 \%$ \\
\hline
\end{tabular}

Persentase kematian tertinggi terdapat pada perlakuan konsentrasi $\mathrm{NaCl} 1 \%$. Menurut Yamashita \& Matsumoto (1997) akumulasi $\mathrm{NaCl}$ berlebih dalam sitoplasma sel dapat menyebabkan perubahan metabolisme di dalam sel, sehingga pertumbuhan dan perkembangan tanaman menjadi terhambat. Hal tersebut mengakibatkan dehidrasi parsial sel dan hilangnya turgor sel karena berkurangnya potensial air di dalam sel. Penelitian Pessarakli (1991) menunjukkan cekaman salinitas menyebabkan terjadinya penghambatan dalam hal penyerapan unsur hara dan pengambilan air mineral dari lingkungan, sehingga menyebabkan penurunan hasil dan pertumbuhan ke arah abnormal. Selain itu, konsentrasi $\mathrm{NaCl}$ yang tinggi dalam kondisi cekaman salin dapat meyebabkan stress berat pada tumbuhan sehingga proses diferensiasi sel ke arah pembentukan organ terhambat.

Perubahan morfologi kalus akibat rusaknya selsel kalus menyebabkan penurunan terjadinya penurunan fisiologi kalus. Penurunan tersebut ditunjukkan dengan tidak adanya pertumbuhan dan perkembangan kalus menuju tahap organogenesis (pembentukan organ-organ tanaman, misalnya tunas). Tanda-tanda tersebut mulai muncul pada penambahan $\mathrm{NaCl}$ dengan konsentrasi $0,25 \%$ dan mencapai puncaknya pada konsentrasi $1 \%$ yang mengakibatkan lebih dari $75 \%$ bagian sel kalus mengalami kematian. Hal ini disebabkan karena adanya molekul $\mathrm{NaCl}$ yang mengalami ionisasi menjadi ion $\mathrm{Na}^{+}$dan $\mathrm{Cl}^{-}$ sehingga terjadi peningkatan salinitas media yang menginduksi terjadinya cekaman ion dan mengakibatkan kematian sel-sel kalus. Lebih jauh lagi, peningkatan konsentrasi $\mathrm{NaCl}$ juga menyebabkan terjadinya penurunan potensial air larutan pada media dan menginduksi terjadinya cekaman air dalam sel. Berdasarkan hasil penelitian Blum (1988), $\mathrm{NaCl}$ dapat bersifat sebagai bahan osmotikum yang dapat menginduksi tiga macam cekaman, yaitu cekaman keracunan mineral akibat adanya garam, cekaman air karena tekanan osmosisnya (osmotikum), dan cekaman nutrisi mineral dalam tanaman karena penyerapan hara terhambat atau dapat berupa gabungan diantara ketiganya. 


\section{Profil Protein}

Berdasarkan hasil uji elektroforesis SDS-PAGE, didapatkan bahwa pada kolom 2 dan 3 berturutturut adalah pita protein perlakuan kontrol pada varietas BL dan PS-862, seperti yang terlihat pada Gambar 2.

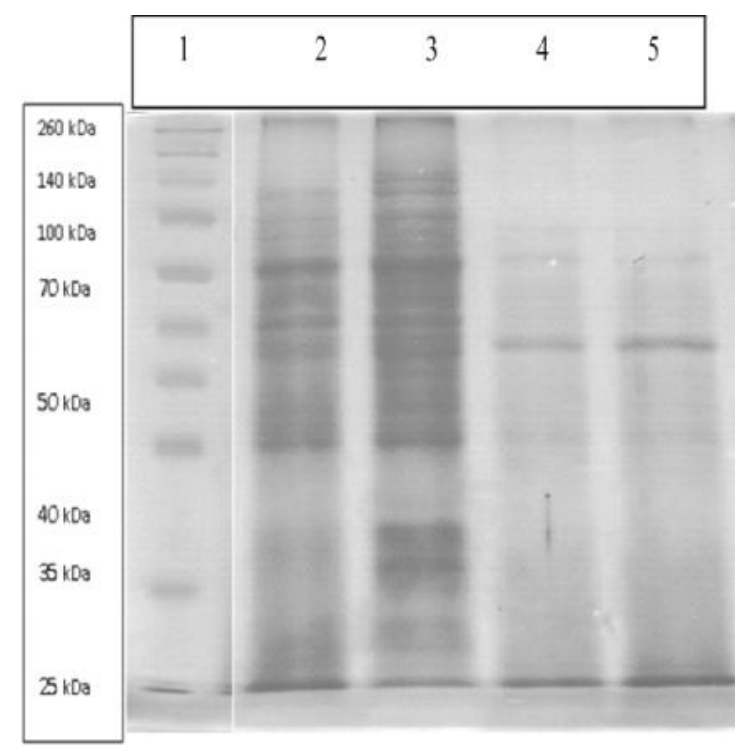

Gambar 2Pita-pita protein hasil uji Elektroforesisi SDSPAGE dengan Marker standard protein.

\section{Keterangan:}

1 : pita protein Marker Standard protein

2: pita protein tebu varietas BL perlakuan kontrol

3: pita protein tebu varietas PS-862 perlakuan kontrol

4 : pita protein tebu varietas $\mathrm{BL}$ perlakuan $\mathrm{NaCl} 1 \%$

5 : pita protein tebu varietas $\mathrm{PS}-862$ perlakuan $\mathrm{NaCl} 1 \%$

Pita protein (protein band) pada kontrol terlihat tebal dan jumlahnya banyak. Sebaliknya pada kondisi perlakuan $\mathrm{NaCl} 1 \%$, pita protein yang muncul pada kedua varietas BL dan PS-862 terlihat tipis dan jumlahnya sedikit, ditunjukkan pada kolom 4 dan 5. Menurut Hanson \& Hitz (1982), tebal atau tipisnya pita protein akan berpengaruh pada besarnya kadar konsentrasi protein yang ada pada suatu sel sehingga menyebabkan kemampuan ekprasi protein pada sel terhambat pada kondisi cekaman salinitas. Hasil pengukuran data konsentrasi protein cenderung menurun pada perlakuan $\mathrm{NaCl} 1 \%$ dibandingkan kontrol pada kedua varietas BL dan PS-862. Gambar 3 menunjukkan nilai ratarata konsentrasi protein varietas BL dan PS 862 pada konsentrasi $\mathrm{NaCl} 0 \%$ (kontrol) dan $1 \%$.

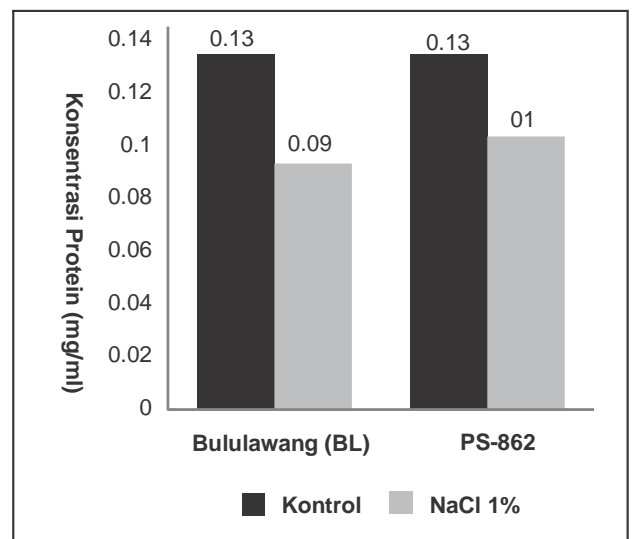

Gambar 3 Nilai rata-rata konsentrasi protein kalus tebu varietas BL dan PS-862 pada perlakuan kontrol dan perlakuan $\mathrm{NaCl} 1 \%$.

Berdasarkan Gambar 3 menunjukkan terjadi penurunan konsentrasi protein pada varietas BL dan PS-862 akibat perlakuan $\mathrm{NaCl} 1 \%$ dibandingkan kontrol. Konsentrasi protein kalus varietas BL sebesar 0,12972 mg/ml pada kontrol, sedangkan pada perlakuan $\mathrm{NaCl} 1 \%$ mengalami penurunan mencapai $0,0975 \mathrm{mg} / \mathrm{ml}$. Hal yang sama juga terjadi kalus tebu varietas PS-862 pada perlakuan kontrol konsentrasi protein sebesar $0,13236 \mathrm{mg} /$ ml, sedangkan perlakuan $\mathrm{NaCl} 1 \%$ mengalami penurunan hingga mencapai $0,09639 \mathrm{mg} / \mathrm{ml}$. Berdasarkan penelitian Irigoyen (1992) kondisi tersebut diakibatkan oleh penurunan sintesis protein dan peningkatan degradasi protein sehingga berpengaruh pada penurunan metabolisme selsel kalus tebu.

Nayer \& Reza (2007), melaporkan bahwa variasi jumlah pita protein menunjukkan adanya respon tanaman terhadap perubahan lingkungan dan pita protein yang hilang menandakan adanya degradasi protein akibat penurunan kualitas lingkungan. Albert et al. (2002) menjelaskan bahwa ketebalan pita protein menunjukkan konsentrasi protein tersebut, dimana protein dengan intensitas yang lebih tebal memiliki 
konsentrasi yang lebih tinggi. Pada perlakuan kontrol dan $\mathrm{NaCl} 1 \%$ terdapat penurunan konsentrasi protein, dikarenakan sel-sel tersebut akan lebih mengekspresikan beberapa protein spesifik dengan menghambat protein lain yang kurang mendukung pada cekaman.

Konsentrasi protein pada kalus tebu perlakuan $\mathrm{NaCl} 1 \%$ mengalami penurunan dibandingkan pada perlakuan kontrol seperti yang terlihat pada Gambar 3. Hal tersebut mempengaruhi jumlah pita protein yang muncul, pada konsentrasi protein yang tinggi akan mampu memunculkan pita protein dalam jumlah banyak. Namun sebaliknya, apabila konsentrasi protein rendah maka pita protein yang muncul akan berjumlah sedikit. Sedikitnya protein yang terekspresi pada perlakuan $\mathrm{NaCl}$ mempengaruhi kondisi morfologi kalus sehingga cenderung mengakibatkan penurunan fungsi-fungsi metabolisme seluler. Kalus mengalami perubahan warna menjadi coklat kehitaman dengan telah mengalami kematian sel-sel penyusunnya sebesar lebih dari $75 \%$. Sebaliknya pada kondisi kontrol dimana protein yang terekspresi maksimal maka proses fisiologis akan cenderung berjalan normal dan tidak berpengaruh pada kondisi morfologi sehingga tidak mengalami perubahan warna kalus.

Beberapa tanaman tertentu, memiliki kemampuan adaptasi dan toleransi terhadap kondisi salin pada lingkungan, sehingga memungkinkan kondisi sel tumbuhan yang mampu bertahan hidup pada kondisi akumulasi ion $\mathrm{Na}$ dan $\mathrm{Cl}$ dalam sel berlebih. Pada penelitian ini, terdapat kurang dari $25 \%$ sel-sel penyusun kalus tebu masih mampu bertahan hidup pada kondisi salin $(\mathrm{NaCl} 1 \%)$. Pada kondisi perlakuan $\mathrm{NaCl} 1 \%$ ini, sel-sel kalus tebu masih mampu bertahan hidup dengan mempertahankan sel-sel penyusunnya walaupun hanya kurang dari $25 \%$ bagian penyusunnya. Sel-sel penyusun kalus mampu melakukan beberapa adaptasi dan mekanisme toleransi terhadap kondisi salin dalam media kultur. Selsel kalus pada perlakuan $\mathrm{NaCl} 1 \%$ cenderung melakukan aktivitas adaptasi terhadap kondisi salin sehingga cenderung mengekpresikan protein yang berpengaruh dalam mengatasi cekaman salin dengan menghambat protein lain. Sehingga kadar protein total cenderung lebih rendah dibanding kondisi kontrol yang sel-sel kalusnya tidak mengalami cekaman salin. Berdasarkan kondisi tersebut, kalus tebu varietas BL dan PS862 pada perlakuan $\mathrm{NaCl} 1 \%$ masih mampu melewati seleksi tahap kalus. Dengan demikian konsentrasi $\mathrm{NaCl} 1 \%$ merupakan konsentrasi kematian untuk kalus tebu sebagai langkah awal dalam proses seleksi untuk mendapatkan tanaman tebu yang toleran salin.

Berdasarkan hasil penelitian menunjukkan bahwa kematian sel kalus sebesar $91,67 \%$ dan sel kalus yang mampu bertahan hidup sebesar 8,33\% pada media MS dengan penambahan $\mathrm{NaCl}$ konsentrasi $1 \%$. Pada perlakuan penambahan $\mathrm{NaCl}$ dalam media tersebut merupakan suatu mekanisme untuk menciptakan kondisi lingkungan hidup yang salin bagi sel-sel kalus tanaman tebu. Sel-sel tersebut masih bersifat aktif membelah dan mudah untuk disub-kultur tanpa mengganggu mekanisme seluler yang terjadi didalamnya. Menurut Xiong et al. (2002), suatu sel tanaman dalam kondisi cekaman abiotik akan memunculkan respon seluler dan molekuler, dengan respon utama berupa transmisi sinyal untuk aktivasi respon adaptif yang biasanya dikenal sebagai transmisi sinyal transduksi cekaman. Sinyalsinyal tersebut akan diterima oleh reseptorreseptor tertentu yang spesifik dengan asal dan tujuan sinyal transmisi. Mekanisme tersebut diregulasi oleh protein, baik itu yang berperan sebagai protein sinyal transduksi maupun reseptor. Pada kondisi tersebut hanya sebagian kecil protein yang terekspresi dan hanya yang bersifat spesifik dibandingkan pada kondisi tercekam. Sehingga pada Gambar 2 didapatkan pita protein 
kalus tebu (S officinarum) varietas BL dan PS862 pada perlakuan media dengan penambahan $\mathrm{NaCl} 1 \%$ yang cenderung lebih sedikit dan tipis dibandingkan pada perlakuan kontrol.

Protein yang muncul pada perlakuan $\mathrm{NaCl} 1 \%$ berjumlah terbatas, beberapa protein diantaranya berperan sebagai sinyal akumulasi berlebih $\mathrm{NaCl}$ ke dalam sel seperti mekanisme. Menurut Marschner (1995) pada dasarnya dalam menghadapi respon cekaman dari lingkungan, kalus tebu akan menanggapi dengan inisiasi recognition (pengenalan cekaman dengan responrespon tertentu) misalnya ketika tercekam salin maka tanggapan yang diterima adalah dengan akumulasi berlebih ion $\mathrm{Na}^{+}$dalam ruang intraseluler. Fungsi protein sebagai regulator dalam berbagai proses metabolisme dan biokimia, sehingga setiap mekanisme yang terjadi pada sel tidak terlepas dari kehadiran protein di dalamnya.

\section{KESIMPULAN}

Berdasarkan penelitian yang telah dilakukan dapat disimpulkan bahwa konsentrasi $\mathrm{NaCl} 1 \%$ menyebabkan kematian kalus sebesar 91.67\% pada kultur jaringan tebu varietas BL dan PS862. Pita protein yang terlihat pada kalus tebu varietas $\mathrm{BL}$ dan PS-862 perlakuan $\mathrm{NaCl} 1 \%$ lebih tipis dibandingkan pada perlakuan kontrol, sehingga pita protein yang terekspresi lebih sedikit.

\section{DAFTAR PUSTAKA}

Albert, B. Johnsons, A. Lewis, J. Raff M. Roberts, K and Walter, P. 2002. Moleculer Biology of The Cell $4^{\text {th }}$. New York: Garland Science. p. 191-263.

Ashraf, M and Foolad, MR. 2007. Improving plant abiotic-stress resistance by exogenous application of osmoprotectants glycine betaine and proline. Journal Environ. Exp. Bot. 59. P. 206-216.

Benyamin, L. 1993. Dasar-Dasar Fisiologi Tumbuhan. Jakarta. Grafindo Persada. hlm: 89-115.
Blum, A. 1988. Plant breeding for stress environment. Crc.press. inc. boca raton. Florida.

Dirjenbun, 2011. Pedoman Teknis Pengelolaan Kebun Benih Tebu dengan Bahan Tanam Bagal Mikro G2. Direktorat Tanaman Semusim. Kementerian Pertanian.

Essa, T.A. and D.H. Al- Ani. 2001. Effect of salt stress on the performance of six soybean genotypes. Pakistan J.of Biological Sci. 4 (2): p.175-177.

Farid, MB. Musa, Y. Nasaruddin dan Darmawan. 2006. Variasi somaklonal tebu tahan salinitas melalui mutagenesis in vitro. Jurnal Agrivigor 5 vol. 3. hlm: 247-258.

Hanson, AD and Hitz, WD. 1982. Metabolic responses of mesophytes to plant water deficits. Ann. Rev. Plant Physiol.33. p.163- 203.

Haryono, 2011. Sambutan kepala badan litbang pertanian dalam acara pembukaan bimbingan teknis pembibitan tanaman tebu. Bogor.

Irigoyen, JJ. Emerich, DW and Sanchez-Diaz, M. 1992. Water stress induced changes in concentrations of prolin and total solubles in nodulated Alfalfa (Medicago sativa) Plants. Physiol. Plant. 84. p. 55-60.

Kusmiyati, F., Purbajanti, E.D.dan Kristanto, B.A. 2009. Karakter Fisiologis, Pertumbuhan dan Produksi Legum Pakan pada Kondisi Salin. Seminar Nasional Kebangkitan Peternakan. Semarang.

Marschner, H. 1995. Mineral nutrition of higher plant $2^{\text {nd }}$ edition. Academic press San Diego. California.

Munns, R., R.A. James, and A. Lauchli. 2006. Aproaches to Increasing the salt tolerance of wheat and other cereals. J. Exp.Bot 57 (5): p.1025-1043. 
Nayer, M dan Heidari, R. 2007. Effects of Drought Stress on Soluble Proteins in two Maize Varieties. Turk Journal Biology. Vol. 32. p. 23-30.

Pathan, S.M.D, J. Lee, J.G. Shannon and H. T. Nguyen, 2007. Recent advances in breeding for drought and salt stress tolerance in soybean (Chapter 30) in M.A. Jenks et al (Eds) Advances in molecular breeding toward drought and salt tolerant crops. p. 739-773.

Pessarakli, m. 1991. Dry matter yield, nitrogen15 absorption, and water uptake by green bean under sodium chloride stress. Journal Crop Sci. 31. p. 1633-1640.

Purwati, RD. Setyo-budi, U dan Sudarsono. 2007. Penggunaan asam fusarat dalam seleksi in vitro untuk resistensi Abaka terhadap Fusarium oxysporum f.sp. cubense. Jurnal Littri vol. 13 No. 2. hlm: 64-72.

Rachman,A., IGM. Subiksa, danWahyunto. 2007. Perluasan areal tanaman kedelai ke lahan suboptimal. Kedelai: Teknik produksi dan pengembangan, p.185226. Puslitbangtan, Bogor.

Turkmen, O. Sensoy, S. Erdal, I. and Kabay T. 2002. Effect of calcium on the emergence and seedling of tomatoes grown in salty growing Media conditions. Yüzüncü Yýl University. Journal Agric. Sci. 12. P. 53-57.
Utama, M. Z. H., W. Haryoko, R. Munir, Sunadi. 2009. Penapisan varietas padi toleran salinitas pada lahan rawa di Kabupaten Pesisir Selatan. J. Agron. Indonesia 37(2): p. 101-106.

Watson, JD. Tooze, J dan Kurtz, DT. 1988. DNA Rekombinan: Suatu Pelajaran Singkat. Jakarta. Erlangga. hlm: 19-25.

Welsh, J.R. 1991. Dasar-dasar Genetika dan Pemuliaan Tanaman. Alih bahasa J.P. Mogea. Penerbit Erlangga. Jakarta.

Welsh, JR. 1991. Dasar-dasar genetika dan pemuliaan tanaman. Erlangga, Jakarta.

Xiong, Limin, Karen, Schumaker, S and Jian, KZ. 2002. Cell signaling during cold, Drought and salt stress. Journal. Plant cells. p. 165-183.

Yamashita, K dan Matsumoto, H. 1997. Effect of Sodium Chloride Stress on the Plasma Membran ATPase of Barley Roots: Probable Cause for Decrease in ATPase Activity. Journal of Plant Nutrition vol 20. p. 233-245. 
